\title{
PEMAHAMAN PARENTING ORANG TUA TERHADAP KESELAMATAN LALU LINTAS UNTUK ANAK USIA DINI DI TK KARYA BUNDA
}

\author{
Alfian Saleh*1, Muthia Anggraini ${ }^{2}$, Sean Marta Efastri ${ }^{3}$ \\ ${ }^{1,2,3}$ Program Studi Teknik Sipil Fakultas Teknik dan Program Studi PG PAUD Fakultas Keguruan \\ Ilmu Pendidikan Universitas Lancang Kuning \\ Jl. Yos Sudarso Km.8 Rumbai Telp.(0761) 53108-53236 Fax.(0761) 52248 \\ *E-mail: alfian.saleh@unilak.ac.id
}

\begin{abstract}
Discipline attitude cannot be formed quickly including in forming traffic discipline. Cooperative learning methods regarding traffic for early childhood is one way to prevent traffic accidents that can be instilled early. Traffic safety education activities for the Karya Bunda Kindergarten in Sei Kijang Subdistrict, Pelalawan District are very necessary because the Karya Bunda Kindergarten is located on the east side roadside which is an accident-prone area with very minimal signs and the absence of the Zona Selamat Sekolah (ZoSS) area. This community service activity uses the method of implementing traffic safety by involving parents as role models for their children. The stages of this activity process are given by the parents the Preetest to measure the parents' initial ability in understanding safety riding, then material and case studies are carried out in planting traffic moral values, especially when carrying children in driving. after being given the material and finally involving the students in coloring the sign image about a case study in driving a vehicle accompanied by parents of students. The results of this activity increased the level of understanding of parents by an average of $25.12 \%$ from the results of the Preetest and Postes. It is hoped that the increase and implementation of orderly traffic can foster awareness of students and parents of TK Karya Bunda's parents to behave safely increase with parents as pioneers.
\end{abstract}

Keywords: Parenting, Safety Education

\begin{abstract}
Abstrak
Sikap disiplin tidak dapat dibentuk secara cepat termasuk dalam membentuk kedisiplinan berlalu lintas. Metode pembelajaran kooperatif mengenai berlalu lintas bagi anak-anak usia dini merupakan salah satu cara pencegahan kecelakaan lalu lintas yang dapat ditanamkan sejak dini. Kegiatan pendidikan keselamatan berlalu lintas untuk TK Karya Bunda Kecamatan Sei Kijang Kabupaten Pelalawan sangat perlu dilakukan karena TK Karya Bunda ini terletak di pinggir jalan lintas timur yang merupakan daerah rawan kecelakaan dengan keadaan rambu-rambu yang sangat minim dan tidak adanya wilayah Zona Selamat Sekolah (ZoSS).Kegiatan Pengabdian masyarakat ini menggunakan metode implementasi keselamatan lalu lintas dengan melibatkan orang tua sebagai role model bagi anak mereka.Tahapan dari proses kegiatan ini orang tua diberikan soal Preetest untuk mengukur kemampuan awal orang tua dalam pemahaman safety riding kemudian dilakukan penyampaian materi dan studi kasus dalam penanaman nilai moral berlalu lintas khususnya saat membawa anak dalam berkendara.Setelah itu diberikan soal Posttest untuk mengetahui pemahaman orang tua setelah diberikan materi dan terakhir melibatkan siswa-siswi dalam mewarnai gambar rambu mengenai studi kasus dalam mengendarai kendaraan dengan didampingi oleh orang tua siswa. Hasil dari kegiatan ini terjadi kenaikan tingkat pemahaman orang tua rata-rata sebesar 25,12\% dari hasil soal Preetest dan Postes. Diharapkan dengan meningkatnya dan menerapkan tertib lalu lintas ini dapat menumbuhkan kesadaran siswa-siswi dan orang tua TK Karya Bunda untuk berperilaku aman meningkat dengan orang tua sebagai pionernya.
\end{abstract}

Kata Kunci: Parenitng, Pendidikan Keselamatan. 


\section{PENDAHULUAN}

Metode dan pola komunikasi yang dijalankan oleh sebagian besar masyarakat merupakan faktor penting dalam membentuk karakter seorang anak. Keluarga kelompok paling kecil dan berperan penting dalam mendidik seorang anak khususnya pada usia dini. Program keayahbundaan (parenting) untuk anak usia dini merupakan program dalam penguatan kehidupan keluarga.Terdapat tiga peran utama dalam program parenting ini yaitu, berkewajiban menciptakan suasana yang hangat dan tenteram,; menjadi panutan yang positif bagi anak; mengajarkan karakter yang baik bagi anaknya. Program parenting ini menitikberatkan kepada orang tua sebagai model yang harus dicontoh oleh anaknya sehingga diharapkan dalam pendidikan keluarga ini memberikan hasil berupa penguatan untuk aksesibilitas masyarakat untuk peningkatan pola asuh dan karakteristik anak dari usia dini.[1].

Tempat pendidikan bagi anak dapat memunculkan dan mengembangkan potensi terbaiknya berada di sekolah. Disekolah anak-anak akan mendapatkan konsep-konsep yang mendasari pola pikir mereka dengan kurikulum yang diajarkan khsusnya pada anak usia dini. Sekolah yang paling dasar dalam mendidik karakter seorang anak pada usia dini adalah pendidikan TK (Taman Kanakkanak). Dimana anak-anak usia dini yang duduk dibangku TK ini mudah untuk menyerap hal-hal baru baik. Untuk itu pada anak usiadini ini perlu penanaman nilai-nilai positif dan yang paling pentingadalah pengetahuan tentang keselamatan lalu lintas yang dibentuk sejak dini karena pola disiplin ini tidak dapat dibentuk secara instan dan harus dibiasakan dan dibudayakan sejak dini karena terkait dengan sikap dan perilaku [2].

Hal yang terpenting dalam menanamkan sikap disiplin berlalu lintas yaitu sekolah-sekolah yang berada langsung didaerah rawan kecelakaaan. Salah satu daerah rawan kecelakaan yang banyak terdapat sekolah yang berada langsung di pinggir jalan adalah di daerah jalan lintas timur. Jalan lintas timur merupakan jalan yang menghubungkan Kota Pekanbaru dengan Kabupaten Siak dan Kabupaten Pelalawan. Jalan ini merupakan jalur yang banyak dilalui kendaraan terutama mobil besar maupun berat dengan kecepatan yang tinggi. Kebanyakan sekolah-sekolah yang berada dipinggir jalan tersebut keberadaan rambu dan Zona Selamat Sekolah (ZoSS) sangat minim dan bahkan cenderung tidak ada. Kondisi ini sangat membahayakan bagi para pengguna jalan terutama anak sekolah. Menurut hasil penelitian yang dilakukan bahwasanya kecepatan kendaraan yang melewati sekolah yang berada di pinggir jalan lintas timur tersebut diatas batas normal kecepatan yang ditentukan baik itu sekolah yang punya ZoSS maupun tidak memiliki ZoSS [3].

\section{METODE}

Metode yang dilakukan pada program pengabdian kepada masyarakat ini terdiri dari tiga tahap yaitu: tahap perencanaan, tahap pelaksanaan dan tahap evaluasi. Pada tahap perencanaan tim pengabdian menentukan tempat/lokasi kegiatan maka dipilihlah di TK Karya Bunda Kecamatan Sei Kijang Kabupaten Pelalawan yang terletak di pinggir jalan Lintas Timur yang termasuk daerah rawan kecelakaan. Kegiatan ini menitikberatkan kepada orang tua siswa-siswi TK Karya Bunda.

Kemudian tahap pelaksanaan, kegiatan ini menggunakan metode ceramah, demonstrasi dan tanya jawab kepada orang tua siswa-siswi. Materi yang disampaikan berupa pengetahuan mengenai safety riding, selain itu juga diselipkan metode demonstrasi dengan memberikan gambaran atau sebuah studi kasus pelanggaran ataupun kebiasaan yang sering dilakukan oleh orang tua dalam berkendaraan khususnya roda dua dengan membawa anaknya saat berkendara. Selanjutnya sesi tanya jawab digunakan untuk melengkapi hal-hal yang belum terakomodasi oleh kedua metode tersebut, simulasi kegiatan diskusi dan konseling penanganan permasalahan terkait keselamatan lalu lintas. Interaksi antara orang tua kepada anaknya dengan memberikan studi kasus ini memberikan pemahaman kepada orang tua bahwasanya orang tua berperan sebagai role model bagi anak mereka. Terakhir selanjutnya tim memberikan games kepada orang tua dan anaknya dalam mewarnai gambar sebuah studi kasus dalam berlalu lintas dengan penerapan rambu-rambu yang berlaku dan arti dari rambu-rambu tersebut yang didampingi oleh orang tua yang merupakan bentuk implementasi pada kegiatan pengabdian ini. 


\section{HASIL DAN PEMBAHASAN}

Pelaksanaan program pengabdian masyarakat ini berupa pendidikan keselamatan di TK Karya Bunda ini diikuti oleh 40 orang tua dari siswa siswi TK. Kegiatan diawali dengan salam, perkenalan dan menghangatkan suasana kelas kepada orang tua.

Setelah itu diberikan soal preetest kepada orang tua siswa-siswi bertujuan untuk mengetahui pengetahuan awal orang tua siswa-siswi. Kemudian selanjutnya memberikan materi oleh pemateri dengan menjelaskan slide yang berisi banyak gambar dan terfokuskan kepada safety riding. Materi yang diberikan dilakukan secara dua arah kepada orang tua siswa-siswi TK dengan proses tanya jawab. Kemudian orang tua siswa-siswi diberikan soal Postest yang bertujuan untuk mengetahui peningkatan pemahaman orang tua siswa-siswi mengenai safety riding.

Kemudian terakhir tim pengabdian melakukan kegiatan demonstrasi penerapan rambu keselamatan. Dengan mengajak siswa dan siswi dalam mewarnai gambar rambu-rambu lalu lintas dan makna dari rambu tersebut. Adapun hasil dari soal preetest dan posttest dapat dilihat pada gambar dibawah ini:

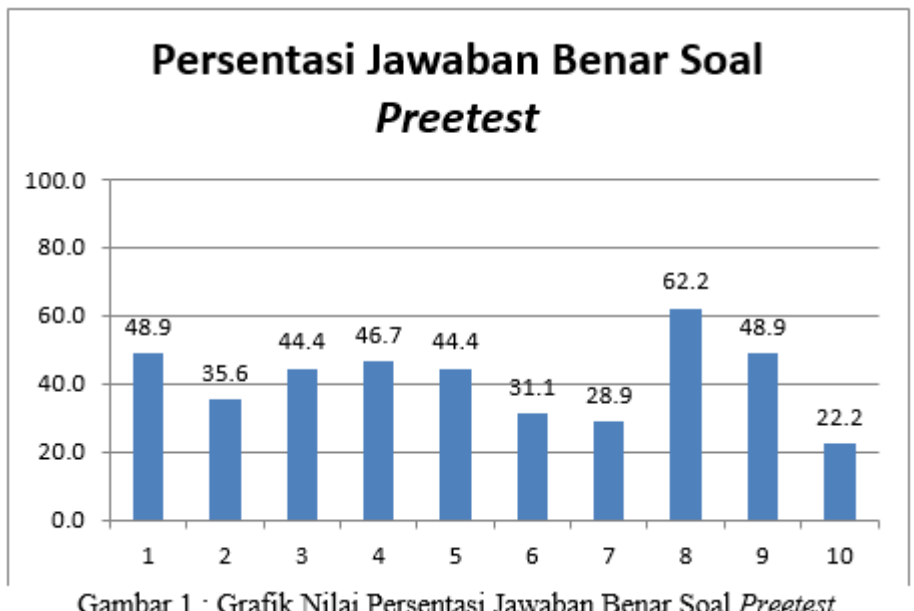

Pada gambar 1 diatas menjelaskan persentasi orang tua yang menjawab benar soal preetest yang diberikan. Soal yang diberikan sebanyak 10 item dengan model pilihan ganda. Soal-soal yang diberikan mengenai safety riding. Dari grafik diatas menunjukkan bahwa rata-rata 41,33\% jawaban yang dijawab orang tua adalah benar ini menandakan pengetahuan awal orang tua mengenai safety riding sangat kurang sehingga memang perlu pengetahuan mengenai safety riding. Setelah dilakukan pemahaman dan materi mengenai safety riding dengan metode ceramah dan tanya jawab dari bebagai studi kasus yang diberikan, orang tua siswa-siswi diberikan lagi soal postest sebanyak 10 item soal dengan hasil pada gambar berikut:

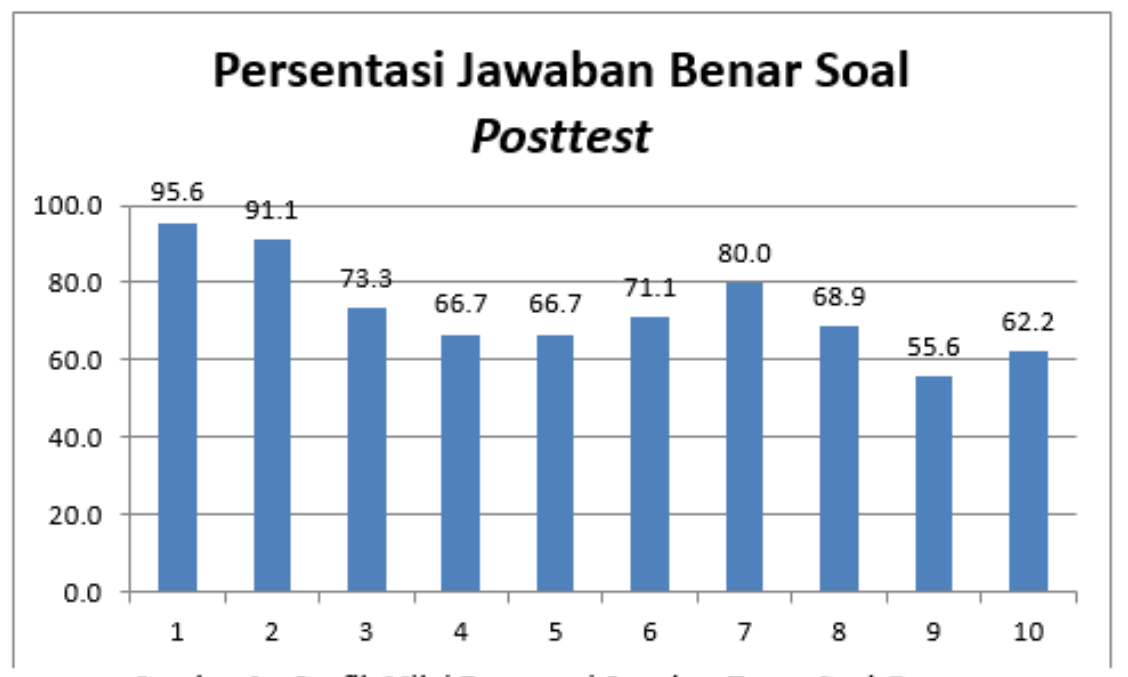

Gambar 2 : Grafik Nilai Persentasi Jawaban Benar Soal Posttest 
Dari gambar grafik diatas menunjukkan bahwa rata-rata $66,45 \%$ dari jawaban yang dijawab orang tua adalah benar ini menandakan bahwa terjadi peningkatan sebesar $25,12 \%$ pemahaman orang tua siswa-siswi mengenai pengetahuan safety riding. Kemudian bentuk dari implementasi pemahaman ini, tim pengabdian melakukan kegiatan interaksi dengan mengajak siswa-siswi untuk mewarnai gambar mengenai studi kasus dalam safety riding dengan menerapkan makna rambudalam sebuah studi kasus tersebut yang didampingi oleh orang tua siswa-siswi.

Secara keseluruhan kegiatan pengabdian di TK Karya Bunda ini berlangsung dengan lancar, sesuai dengan waktu yang ditentukan serta mendapatkan perhatian yang cukup baik dari seluruh pihak sekolah. Adapun kendala yang ditemukan adalah dalam membuat tertib siswa siswi agar disiplin dalam duduk berbaris selama mengikuti kegiatan dan juga membuat siswa siswi tetap fokus selama berlangsungnya kegiatan. Fun learning yang diterapkan dapat membuat $75 \%$ siswa siswi benar-benar mengikuti jalannya kegiatan dengan optimal.

Kemampuan kognitif anak pada usia dini sangat mempengaruhi dalam tingkat pemahaman anak khususnya pemahaman mengenai keselamatan berlalu lintas. Pada dasarnya anak usia sekolah sudah mampu dalam membedakan arti dari konsep selamat dan tidak selamat dalam berlalu lintas, namun kemampuan kognitif mereka masih berada pada tahap praopersional sehingga mereka tidak mampu menggunakan sudut pandangnya dalam menghadapi situasi tertentu maka pada situasi praktis anak usia dini lebih mengandalkan interpretasi sendiri tentang apa yang dianggap selamat dan tidak selamat [4]. Ada beberapa faktor-faktor yang mempengaruhi pengetahuan seseorang yaitu usia, pendidikan, pengalaman, media massa dan sosial budaya. Sebagai contoh, anak-anak pada usia dini mengira jika mereka bisa melihat pengendara kendaraan bermotor mendekati mereka yang sedang menyeberang jalan, maka pengendara tersebut juga bisa melihat mereka dengan jelas. Anakanak ini tidak mempertimbangkan adanya kemungkinan pandangan pengendara kendaraan bermotor bisa terhalang oleh banyak hal, seperti tikungan tajam sebagai akibat dari ketidakakuratan penilaian ini, anak-anak yang usianya muda rentan mengalami kecelakaan di jalan raya, bahkan di jalan raya sekalipun. [5].

\section{KESIMPULAN}

Beberapa kesimpulan dari kegiatan pengabdian masyarakat ini adalah terjadi kenaikan sebesar $25,12 \%$ pemahaman orang tua siswa-siswi yang menjawab benar pada soal preetest dan menjawab benar pada soal postest. Orang tua dan siswa-siswi sangat antusias dalam kegiatan ini karena tim pengabdian memberikan games kepada peserta dalam mewarnai gambar rambu-rambu dalam studi kasus dan memberikan makna dari gambar rambu-rambu yang diwarnai tersebut. Sehingga dalam kegiatan ini ada interaksi langsung antara anak dengan orang tua dalam memahami safety riding.

\section{SARAN}

Berdasarkan simpulan di atas, maka saran yang dapat diberikan adalah sebagai berikut:

1. Pada saat pembelajaran metode kooperatif ini, perlu memperhatikan petunjuk-petunjuk dan keseriusan orang tua dalam berinteraksi dengan anaknya

2. Penerapan metode pembelajaran kooperatif sebagai alternatif atau pilihan dalam praktik pembelajaran keselamatan lalu lintas terbukti dapat meningkatkan pemahaman tentang keselamatan lalu lintas.

\section{DAFTAR PUSTAKA}

[1] Akhyadi, A. S., \& Mulyono, D. (2018). Program Parenting Dalam Meningkatkan Kualitas Pendidikan Keluarga (Program Pengabdian di Desa Karangpakuan Kecamatan Darmaraja, Kabupaten Sumedang). Pengabdian Kepada Masyarakat (Abdimas) IKIP Siliwangi, 1(1), 1-8.

[2] Saleh, A., Anggraini, M., Efastri, S. M., Kuning, U. L., Yos, J., \& Km, S. (2018). Implementasi Keselamatan Lalu Lintas Pada Anak Usia Dini Dengan Metode Pendekatan Pembelajaran Kooperatif Tipe Role Playing. Dinamisia, 2(1), 42-46

[3] Soehardi, F., Studi, P., Sipil, T., Lancang, U., Putri, L. D., Studi, P., ... Sekolah, Z. S. (2017). Tinjauan Kecepatan Kendaraan Pada Wilayah ZoSS Di Jalan Lalu Lintas Timur Provinsi 
DINAMISIA - Jurnal Pengabdian Kepada Masyarakat $\quad$ Vol. 3, Special Issue Juni 2019, Hal. 44-48

Riau. Teknik Sipil Siklus, 3(2), 77-85.

[4] Maakip,L, Sulaiman, W.S.W., Ismail,R, \& Jaafar, W.A.W. (2000), Pengetahuan kanakkanak terhadap aspek-aspek keselamatan diri: Satu kajian awal Seminar Psikologi-Psima

[5] Sujiono, Yuliani Nurani.2009.Konsep Dasar Pendidikan Anak Usia Dini.Jakarta 